\title{
Do Better Workplace Environmental Conditions improve Job Satisfaction?
}

\author{
Amaya Erro-Garcés * \\ Public University of Navarre \\ Campus Arrosadía s/n \\ 31006 Pamplona, Navarra, Spain \\ amaya.erro@unavarra.es \\ Susana Ferreira \\ University of Georgia \\ Athens, CAES Campus \\ sferreir@uga.edu
}

AG \& Applied Economics, 314D Conner Hall, Athens, GA 30602

\section{Abstract:}

Using data from the Sixth European Working Conditions Survey collected in 2015 we estimate the contribution of workplace environmental factors to the job satisfaction of about 44,000 Europeans from 35 countries. Our analysis shows that environmental conditions play an important role in explaining job satisfaction, comparable to contract conditions such as pay increases and contract duration. Interestingly, these results are not driven by the perception of health or safety risks associated with worse environmental conditions.

Highlights:

- Safe and healthful working conditions are not only required by law but may also be smart business.

- Poor environmental conditions at the workplace are negatively associated with job satisfaction.

- Vibrations and low temperatures are factors most strongly related to job satisfaction.

- Environmental factors are linked to job satisfaction and to perception of health or safety risks.

- Workplace "climate" has a significant positive impact on job satisfaction.

Keywords: Job satisfaction; job characteristics; working contract factors; physical environmental conditions

Corresponding author: 
Amaya Erro-Garcés. Public University of Navarre. Campus Arrosadia, 31006,

Pamplona, Navarra, Spain. Tel. 0034948 169081. Email: amaya.erro@unavarra.es 


\section{Highlights:}

- Safe and healthful working conditions are not only required by law but may also be smart business.

- Poor environmental conditions at the workplace are negatively associated with job satisfaction.

- Vibrations and low temperatures are factors most strongly related to job satisfaction.

- Environmental factors are linked to job satisfaction and to perception of health or safety risks.

- Workplace "climate" has a significant positive impact on job satisfaction. 


\section{Introduction}

Preoccupation about the job satisfaction of employees has increased among companies from all over the world. This preoccupation is not necessarily altruistic; more satisfied workers are more productive, as shown in both survey and experimental studies. The meta-analysis of Harter et al. (2002) shows that more satisfied workers are less likely to be absent or quit, and that job satisfaction and employee engagement are related to firm performance including higher productivity and profitability. In 2015, 88 percent of US employees reported that they were satisfied with their job overall, marking the highest level of job satisfaction over the last ten years (SHRM, 2016).

From a public policy standpoint, because a job is a fundamental part of many people's life, understanding job satisfaction is an integral part of understanding overall life satisfaction. Although monthly earnings is one of the foremost predictors of work satisfaction, having employees satisfied implies further aspects than just earning high salaries. For example, giving workers more control over their schedules, environment and work habits gives them a sense of accomplishment rather than obligation (Shetrone 2011). Moreover, as economies slowly but steadily continue to grow after the Great Recession and labor markets tighten, some companies are turning to alternative ways to compensate their employees in lieu of annual pay rises (Mui 2015), which may be one of the reasons of stagnant real wages in leading world economies (IMF 2017).

More than forty years ago, Seashore and Taber (1975) systematically classified a myriad of variables associated to job satisfaction into a taxonomy (see Figure 1). In Seashore and Taber's framework, which remains dominant in the literature to this date, the variables correlated with job satisfaction can be grouped into several categories: individual characteristics including abilities and demographic and personality traits; characteristics of the job, including pay, variety, but also environmental factors such as 
noise; organizational characteristics, which would include things like the workplace "climate" and possibilities of advancement; occupation characteristics (power, prestige); and macro-economic and political environment. In this context, the provision of safe and healthful working conditions for working men and women by employers is not only required by law (e.g. the Occupational Safety and Health Act of 1970 in the United States or the European Framework Directive on Safety and Health at Work -Directive 89/391 EEC) but it may also be smart business.

\section{INSERT FIGURE 1 HERE}

Many papers have estimated the relative contribution of demographic, job and organizational characteristics and macroeconomic factors to job satisfaction in specific countries (e.g. Beckmann et al. 2009, Mohr and Zoghi 2008, Böckerman et al. 2015, Green et al. 2016), across countries (e.g. Blanchflower and Oswald 1999, Souza-Poza et al. 2000, Clark 2005, Augner 2015, Clark 2015, De Neve and Ward 2017), or focused on the role of a specific set factors (e.g. age in Clark et al. 1996, relative pay in Card et al. 2012, gender and pay in Mumford and Smith 2014). The consensus from the literature is that there is no significant difference between women and men in their satisfaction in job, and job satisfaction is U-shaped in age. Job and organizational characteristics positively related to job satisfaction are job security, being in a small workplace, having high relative earnings, functional flexibility, high involvement management practices, being self-employed, low commuting time, being a supervisor, working for the public sector or having a university degree. See also Appendix table 1.

Environmental factors such as noise in the workplace do appear in Seashore and Taber's framework (under "Job and Job Environment" in the right panel), but the analysis of the impact that environmental factors have in the workplace and how they influence job satisfaction has received considerably less attention than other 
characteristics. As environmental factors have not been systematically analyzed in large cross-national surveys, we lack a robust understanding of the impact of workplace health and safety on workers' well-being, including how the impact of environmental working conditions on work satisfaction varies across national settings and how much they matter compared to other job and organizational characteristics. Addressing this gap is precisely the contribution of our research paper.

That being said, there is a plethora of case studies studying the impact of specific features of the working environment such as lighting systems or physical workplace configurations in employee's performance and job satisfaction. A search of the terms "lighting and worker productivity" in Google Scholar yields about 50,000 results. However, most of this literature consists of case field studies in factory or office settings with small sample sizes, and it is not clear if their findings generalize to broader contexts. A notable exception is the work of Green et al. (2013), who examined trends in non-wage aspects of job quality in Europe, such as work quality, work intensity, good physical environment, and working time quality using 1995 to 2010 data of the European Working Conditions Survey.

In addition to using the most recent data from the European Working Conditions Survey (2015 data) our study differs from Green et al.'s in three important ways. First, we focus on estimating the impact of environmental conditions on job satisfaction rather than on constructing indices of overall job quality. Second, we employ a multivariate regression analysis that compares the relative contribution to job satisfaction of environmental conditions vis-a-vis individual, organizational, and other job characteristics. Third, Green et al. lump together different work characteristics into an index, while our estimations attempt to shed light on the potentially different contributions of each environmental factor. 
In summary, compared to previous papers that have just focused in a specific country, worked on older data, or ignored environmental variables as potential factors explaining job satisfaction, our paper 1) conducts a systematic cross-national analysis including data from 35 countries and about 44,000 respondents; 2) uses new data from the Sixth European Working Conditions Survey collected in 2015 and published in $2017 ; 3$ ) focuses on the contribution of environmental factors to job satisfaction.

The rest of the paper proceeds as follows. Section 2 describes the data. Section 3 presents the econometric model. Results are shown in Section 4. Section 5 concludes and offers some suggestions for future research.

\section{Data}

The empirical analysis uses data from the sixth wave of the European Working Conditions Survey (EWCS). ${ }^{1}$ Data from EWCS were gathered from September to December 2015 through face to face interviews, carried out at the respondent's home, with an average duration of 45 minutes. This questionnaire collected information on demographic characteristics of the respondents as well as a broad range of factors affecting job satisfaction such as physical and psychosocial risk factors, employee participation, learning factors, gender issues, physical environment, and social relations at work. We complement the EWCS data with macroeconomic variables: GDP per capita and unemployment rates, collected from Eurostat.

We use data from 28 EU Member States, as well as Norway, Switzerland, Albania, the Former Yugoslav Republic of Macedonia, Montenegro, Serbia and Turkey (a total of 35 countries, with an overall sample size $n=43,850$ ). The target sample size for the sixth EWCS is 1,000 interviews per country, but it is increased in several

\footnotetext{
${ }^{1}$ The EWCS is publicly available from the European Foundation for the Improvement of Living and Working Conditions (https://www.eurofound.europa.eu/).
} 
countries to reflect the larger workforce of larger countries. For that reason, all analyses are weighted with supra-national sample weights to ensure cross-country comparability. The definitions and descriptive statistics of the variables considered in our analysis are shown in Table 1.

The dependent variable in our empirical estimation 'Job Satisfaction' (JS), is sourced from the answers to a job satisfaction question ("On the whole, are you very satisfied, satisfied, not very satisfied or not at all satisfied with working conditions in your main paid job?"), which we converted to a 1-4 scale from "not at all satisfied" to "very satisfied". With an average job satisfaction of 3.093, workers in our sample report to be "satisfied" (Table 1). Most of the respondents are either satisfied (58.8\%) or very satisfied (25\%) with their jobs (Figure 2), although there are important crossnational differences. People in Denmark, Norway, Austria, Switzerland, United Kingdom and Ireland are on average the happiest in their workplace whereas Eastern Europeans workers are the least satisfied.

\section{INSERT FIGURE 2 HERE}

The independent variables in Table 1 are grouped into the five categories that correspond to the taxonomy mentioned earlier: individual factors (I), working contract conditions $(\mathrm{C})$, job and organizational characteristics $(\mathrm{J})$, macroeconomic factors $(\mathrm{M})$, and physical environmental factors (E).

Individual factors $(I)$

Our vector of demographic variables includes gender, education level, age, number of children, and marital status. These are variables whose importance to explain job satisfaction is widely accepted in the literature (see e.g. Blanchflower and Oswald 1994, Clark et al. 1996, Oswald 2002, Mumford and Smith 2014). To allow for a non-linear effect of age (Clark et al. 1996), we also include age squared. 


\section{Working contract conditions $(C)$}

Wages are an important determinant of job satisfaction (Clark et al. 1996, Card et al. 2012) and we include the monthly net wage in our regressions. In addition, we also account for salary changes in the last year, with an ordinal variable that ranges from 1 ("decreased a lot") to 6 ("increased a lot"). To proxy for job security at the current employment, we consider the duration of the contract (an ordinal variable ranging from 1 , having no contract, to 6 , having a contract of unlimited duration). We also account for the number of hours per week an employee wishes to work.

\section{$J o b$ and organizational characteristics $(J)$}

We control for the size of the company with four dummy variables; self-employment (1 employee), small firms (2 to 9 employees), medium-size firms (10 to 249 employees), with large firms (more than 250 employees) as the reference group. We also account for the type of company with dummies for whether the respondent works in a private company, a public company, a joint private-public company, or an NGO. In this line, Böckerman, Bryson and Ilmakunnas (2012) considered public employer as a control variable.

In order to capture other intangible characteristics that determine the "climate" and possibilities for professional growth and engagement in the workplace, we use six ordinal variables. The first one measures the stress experienced at work, ranging from 1 ("always") to 5 ("never"), i.e. larger values denote more stress. The other five variables are constructed from 5-point Likert-scale questions and measure the level of involvement in improving the workplace, the degree to which the immediate boss provides useful feedback, the degree of trust on the employee by management, prospects for career advancement, and good relationships with colleagues. In all the cases, the scale ranges from 1 ("strongly disagree") to 5 ("strongly agree"). 


\section{Macroeconomic factors $(M)$}

There is no question that being unemployed has a very negative effect on subjective well-being. That the unemployed evaluate their overall life satisfaction less highly and experience more negative and fewer positive emotions in their daily life are among the most widely accepted and replicated findings in the "economics of happiness" literature (see e.g., Clark and Oswald 1994, Winkelmann and Winkelmann 1998, Helliwell and Huang 2014, De Neve and Ward 2017). In addition, the unemployment rate as well as the overall state of the national economy (captured by GDP per capita), influence the perception of job security for those employed and can have a direct impact on their job satisfaction as well. By signaling poor labor market conditions and frequent redundancies, high levels of unemployment might, on the one hand heighten the sense of job insecurity while simultaneously create a sense of relief for those who have a job (Beckman et al., 2009; De Neve and Ward, 2017). We control for these two variables with data at the national level from Eurostat.

\section{Physical environment variables $(E)$}

In 2015 the EWCS measured a broad range of physical environmental factors at the work place. Their contribution to workers' satisfaction is the focus of this paper. The EWCS questionnaire asked workers about the exposure at work to a number of potentially unpleasant and/or unhealthy conditions: (1) vibrations from hand tools, machinery, etc.; (2) noise ("so loud that the employee would have to raise his or her voice to talk to people"); (3) high temperatures ("which make you perspire even when not working"); (4) low temperature ("whether indoors or outdoors"); (5) breathing in smokes, fumes (such as welding or exhaust fumes), power or dust (such as wood dust or mineral dust), etc.; (6) breathing in vapours such as solvents and thinners; (7) handling or being in skin contact with chemical products or substances; (8) second hand 
smoking; and (9) handling or being in direct contact with materials which can be infectious, such as waste, bodily fluids, laboratory materials, etc.. From these questions, we construct ordinal variables that measure the degree of exposure from 1 ("never") to 7 ("all the time").

The dataset does not offer readings from sound level meters, thermometers, or air quality monitoring devices installed at the workplace. The variables we include in the analysis measure the environmental conditions at work as perceived by the individual respondent instead, which are, arguably, a more important determinant of their work experience.

In addition to information about specific environmental conditions, the survey collected information on whether respondents thought that their health and safety was at risk because of their work. It takes the form of a dummy (yes=1/no=0) variable.

\section{INSERT TABLE 1 HERE}

\section{Methods}

We model job satisfaction (JS) as determined by individual factors (I), working contract conditions (C), job and organizational characteristics (J), macroeconomic factors (M) and physical environmental factors (E), according to the framework in Seashore \& Taber (1975). Thus, we estimate the following equation:

$J S_{i j k}=\alpha+\boldsymbol{\beta}_{\mathbf{0}}^{\prime} \boldsymbol{I}_{\boldsymbol{i}}+\boldsymbol{\beta}_{\mathbf{1}}^{\prime} \boldsymbol{C}_{\boldsymbol{i j}}+\boldsymbol{\beta}_{2}^{\prime} \boldsymbol{J}_{\boldsymbol{j}}+\boldsymbol{\beta}_{\mathbf{3}}^{\prime} \boldsymbol{M}_{\boldsymbol{k}}+\boldsymbol{\beta}_{\mathbf{4}}^{\prime} \boldsymbol{E}_{\boldsymbol{j}}+\gamma_{k}+\varepsilon_{i j k}$

where $i$ denotes individual at job $j$ in country $k$ and $\gamma_{k}$ are country dummies. Although we control for two key macroeconomic factors: GDP per capita and unemployment rate, countries differ across many dimensions (from strength of labor unions to cultural and 
social norms) that may affect job satisfaction. The country-specific constants absorb the impact of those potentially important omitted variables.

Equations (1) can be estimated by ordinary least squares (OLS) or, given the ordinal nature of our dependent variable Job Satisfaction, by using either ordered-probit or logit models. As in previous studies that have applied both approaches, we find little qualitative difference between the results of the two (see e.g. Ferrer-i-Carbonell and Frijters, 2004, or Angrist and Pischke, 2009). Our discussion and the results we present below focus on the OLS results as their coefficients can be readily interpreted as partial marginal effects.

While the regressions include country-specific constants, and we are able to control for a broad range of variables, mitigating concerns of omitted variable bias, one important methodological concern is the potential endogeneity (reverse causality) between job satisfaction and a number of independent variables. Individuals that are happier with their work may be more likely to be more productive and earn more in the first place, or to get on well with colleagues, be trusted and receive feedback from management. This means that the cross-sectional results reported in the next section- as in much of this literature - cannot be interpreted as casual effects.

\section{Results}

In order to isolate the influence of environmental factors on job satisfaction, we estimate (1) sequentially. We first estimate a 'conventional' JS equation, which includes individual socio-demographic information, characteristics of the job and the organization and macroeconomic factors, to then add the environmental conditions to the regression model. Table 2 presents the results. 
In all of our regressions, we report the standardized (beta) coefficients. That is, we standardize all the variables such that they each have a mean of 0 and a standard deviation of 1 . This enables us to more easily compare the magnitude of the coefficients, especially as the variables are measured in different units (for example, monthly earnings is measured in Euro and the number of hours an employee wishes to work is measured in hours). The standardized coefficients measure by how many standard deviations the dependent variable changes per standard deviation increase in the explanatory variable. Consistent with previous literature (e.g. Oswald 1999; Clark, Oswald and Warr 1996), age has a U-shape relationship with JS, but with a turning point at less than one year of age, it is a de facto positive association. Having more children is also associated with higher JS. Perhaps the most interesting result in column (1) is that after controlling for individual characteristics, job, organizational characteristics and other contract conditions, monthly earnings is statistically insignificant. This stands in contrast with salary change which is positive and statistically significant. In combination, these findings suggest that individuals adapt to their (absolute) level of earnings and that it is the change, or the current earnings relative to past earnings that matter. This results are consistent with Diriwaechter and Shvartsman (2017) who find that after a wage increase, German workers tended to be more satisfied with their jobs. In line with intuition, job security at the current employment, as measured by the duration of the contract, has as positive relation with JS, while those who feel underemployed -that is, who wish to work additional hoursreport lower JS.

Compared to those who work in large firms, those employed by medium-size or small firms, and those who are self-employed, report a higher JS. The type of firm also matters, with those not working in the private sector reporting lower JS. 
The set of characteristics with the largest contribution to JS in column (1) are the less tangible characteristics related to workplace climate. These are the variables that measure the quality of relationships with colleagues and superiors, whether the job allows for high involvement, offers possibilities for professional growth, and is stressful. Except for the variable that measures stress at work, all the variables have intuitive positive signs. Regarding the also positive (although counterintuitive) association between experiencing stress at work and job satisfaction, it may be due to the variable stress capturing unobserved job characteristics (such as degree of responsibility or transcendence). This is despite our efforts to include a wide range of individual and job characteristics to mitigate omitted variable bias.

In column (2), most the variables capturing the environmental conditions in the workplace are statistically significant and, except for noise exposure, have the expected signs. Being exposed to second hand smoking, breathing vapours (such as solvent and thinners) and, more prominently, exposure to vibrations and low temperatures are statistically significant and negatively associated with job satisfaction. In order to put their contribution to JS into perspective, we can compare their estimated coefficients, to those of other job characteristics; their magnitudes are similar to those of important contract conditions such as salary change and contract duration. Including environmental conditions in the JS regression slightly improves the adjusted R-squared. The perception of health or safety risks at work has a strong negative association with JS. As column (3) shows, its magnitude (-0.12) is comparable to that of the work climate characteristics. The importance of environmental conditions at the workplace to explain JS is not driven solely by the perception of health and safety risks, however. In column (4) that includes both sets of variables, it is apparent that although the coefficients on being exposed to vibrations, low temperatures and second-hand smoking 
diminish slightly, they continue to be statistically significant (at a $1 \%$ level for the first two).

\section{INSERT TABLE 2 HERE}

\section{Conclusions}

Job satisfaction is related to the extent to which people like or dislike their jobs. A vast literature aims to understand the determinants of job satisfaction in order to improve the attitude of workers towards their jobs and, ultimately, their productivity and well-being. Environmental conditions at the workplace are regulated in most countries, suggesting that they are an important determinant of worker's physical and emotional well-being. Nevertheless, compared to other job and organizational characteristics (such as pay or work "climate"), the role of environmental factors on explaining job satisfaction has not received much attention in the academic literature. This paper addresses this gap.

We use data from the latest round of the European Working Conditions Survey, which contains information on the self-reported exposure to a number of environmental conditions at the workplace: noise, vibrations, high and low temperatures, breathing smoke, fumes and dust, breathing vapors, chemical products, second-hand smoking and infectious material. We conduct multivariate regressions to find the contribution of these environmental factors vis-à-vis other individual and job characteristics to the job satisfaction of over 44,000 Europeans.

As expected, we find that poor environmental conditions at the workplace are negatively associated with job satisfaction. Of all the conditions for which information was collected, exposure to vibrations as the most relevant factor, followed by low temperatures and second-hand smoking. Overall, the magnitude of these effects is comparable to that of other important job characteristics: changes in compensation and job security. Regarding the former, while the absolute level of earnings is not significant 
to explain job satisfaction, salary changes are. In addition to environmental conditions, the perception of health or safety risks at work has a negative association with job satisfaction. This association is strong but does not fully explain the relationship between environmental factors and job satisfaction.

Taken at face value, our results suggest that regulations enshrined to protect the health and safety of working men and women, by improving environmental conditions at the workplace can improve job satisfaction and thus can be "good for business." Our study is, however, limited by the cross-sectional nature of the data - which prevents us from establishing causal effects. Additional research in this area would benefit from the use of panel data and from a more detailed analysis of the mechanisms through which environmental conditions affect workers' well-being, in addition to their job satisfaction. 


\section{References}

Angrist, J. \& Pischke, J. (2009). Mostly Harmless Econometrics, Princeton University Press.

Arampatzi, E., Martijn J. B., \& Ruut V. (2015). "Financial distress and happiness of employees in times of economic crisis." Applied Economics Letters 22 (3): 173179.

Augner, C. (2015). Job satisfaction in the European Union: The role of macroeconomic, personal, and job-related factors. Journal of occupational and environmental medicine, 57(3), 241-245.

Beckmann, M., Cornelissen, T., \& Schauenberg, B. (2009). "Fixed-term employment, work organization and job satisfaction: evidence from German individual-level data". Working-paper.

Blanchflower, D. G., \& Oswald, A. J. (1999). "Well-being, insecurity and the decline of American job satisfaction". NBER working paper, 7487.

Böckerman, P., Bryson, A., \& Ilmakunnas, P. (2012). "Does high involvement management improve worker wellbeing?". Journal of Economic Behavior \& Organization, 84(2), 660-680.

Brown, D., \& McIntosh, S. (1998). "If you're happy and you know it... job satisfaction in the low wage service sector". Centre for Economic Performance, London School of Economics and Political Science.

Burchell, B. (1994). "The effects of labour market position, job insecurity and unemployment on psychological health". In D. Gallie, C. Marsh, \& C. Vogler (Eds.), Social change and the experience of unemployment (pp. 188-212). Oxford: Oxford University Press.

Card, D., Mas, A., Moretti, E., \& Saez, E. (2012). "Inequality at work: The effect of peer salaries on job satisfaction". American Economic Review, 102(6), 29813003.

Clark, A. E. (2005). "Your money or your life: Changing job quality in OECD countries." British Journal of Industrial Relations, 43(3), 377-400.

Clark, A. E. (2015). "What makes a good job? Job quality and job satisfaction". IZA World of Labor.

Clark, A. E., \& Oswald, A. J. (1994). "Unhappiness and unemployment". The Economic Journal, 104(424), 648-659.

Clark, A., Oswald, A., \& Warr, P. (1996). "Is job satisfaction U-shaped in age?". Journal of occupational and organizational psychology, 69(1), 57-81.

De Neve, J. E., \& Ward, G. (2017). "Happiness at work". Saïd Business School, Working-Paper 2017-07.

Diriwächter, P., \& Shvartsman, E. (2018). "The anticipation and adaptation effects of intra-and interpersonal wage changes on job satisfaction". Journal of Economic Behavior \& Organization, 146, 116-140.

Eurofound (2016). Sixth European Working Conditions Survey: Overview report. Publications Office of the European Union, Luxembourg.

Ferrer-i-Carbonell, A. \& Frijters, P. (2004). "How Important is Methodology for the Estimates of the Determinants of Happiness?" The Economic Journal 114(497): 641-659.

García-Mainar, I., Montuenga, V. M., \& Navarro-Paniagua, M. (2015). "Workplace environmental conditions and life satisfaction in Spain". Ecological Economics, 119, 136-146. 
Green, F., Felstead, A., Gallie, D., \& Inanc, H. (2016). "Job-related well-being through the Great Recession". Journal of Happiness Studies, 17(1), 389-411.

Green, F., Mostafa, T., Parent-Thirion, A., Vermeylen, G., Van Houten, G., Biletta, I., \& Lyly-Yrjanainen, M. (2013). "Is job quality becoming more unequal?". ILR Review, 66(4), 753-784.

Harter, J. K., Schmidt, F. L., \& Hayes, T. L. (2002). "Business-unit-level relationship between employee satisfaction, employee engagement, and business outcomes: a meta-analysis". Journal of applied psychology, 87(2), 268.

Helliwell, J.F., \& H. Huang (2014). "New measures of the costs of unemployment: Evidence from the subjective well-being of 3.3 million Americans". Economic Inquiry, 52(4), 1485-1502

International Monetary Fund (2017). World Economic Outlook: Gaining Momentum? Washington, April.

Mayer, A. (2015). "Recession and life satisfaction in 35 countries". International Journal of Happiness and Development, 2(2), 118-136.

Mohr, R. D., \& Zoghi, C. (2008). "High-involvement work design and job satisfaction". ILR Review, 61(3), 275-296.

Mui, Y. Q. (2015) "Companies have found something to give their workers instead of raises" The Washington Post, July 282015.

Mumford, K., \& Smith, P. N. (2015). "Peer salaries and gender differences in job satisfaction in the workplace". The Manchester School, 83(3), 307-313.

Origo, F., \& Pagani, L. (2008). "Workplace flexibility and job satisfaction: some evidence from Europe". International Journal of Manpower, 29(6), 539-566.

Osterman, P. (2013). "Introduction to the special issue on job quality: What does it mean and how might we think about it". ILR Rev.66 (4).

Oswald, A. (2002). Are you happy at work? Job satisfaction and work-life balance in the US and Europe. Warwick WBS Event, Warwick Hotel, New York, NY, 5.

Seashore, S. E., \& Taber, T. D. (1975). "Job satisfaction indicators and their correlates". American behavioral scientist, 18(3), 333-368.

Shetrone, A., (2011) 7 Ways to Improve Employee Satisfaction, Inc.

Society for Human Resources Management (2016) Employee job satisfaction and engagement - Revitalizing a changing workforce.

Sousa-Poza, A., \& Sousa-Poza, A. A. (2000). "Well-being at work: a cross-national analysis of the levels and determinants of job satisfaction". The journal of socioeconomics, 29(6), 517-538.

Tay, L., \& Harter, J. K. (2013). "Economic and labor market forces matter for worker well-being". Applied Psychology: Health and Well-Being, 5(2), 193-208.

Viñas-Bardolet, C., Velazco, J., \& Torrent-Sellens, J. (2015). "Determinants of Job Satisfaction, the Role of Knowledge-based work: An illustration from Spain". Internet Interdisciplinary Institute (IN3), Open University of Catalonia (UOC), Barcelona, Spain.

Winkelmann, L., \& Winkelmann, R. (1998). Why are the unemployed so unhappy? Evidence from panel data. Economica, 65, 1-16. 
INSERT APPENDIX TABLE 1 HERE 


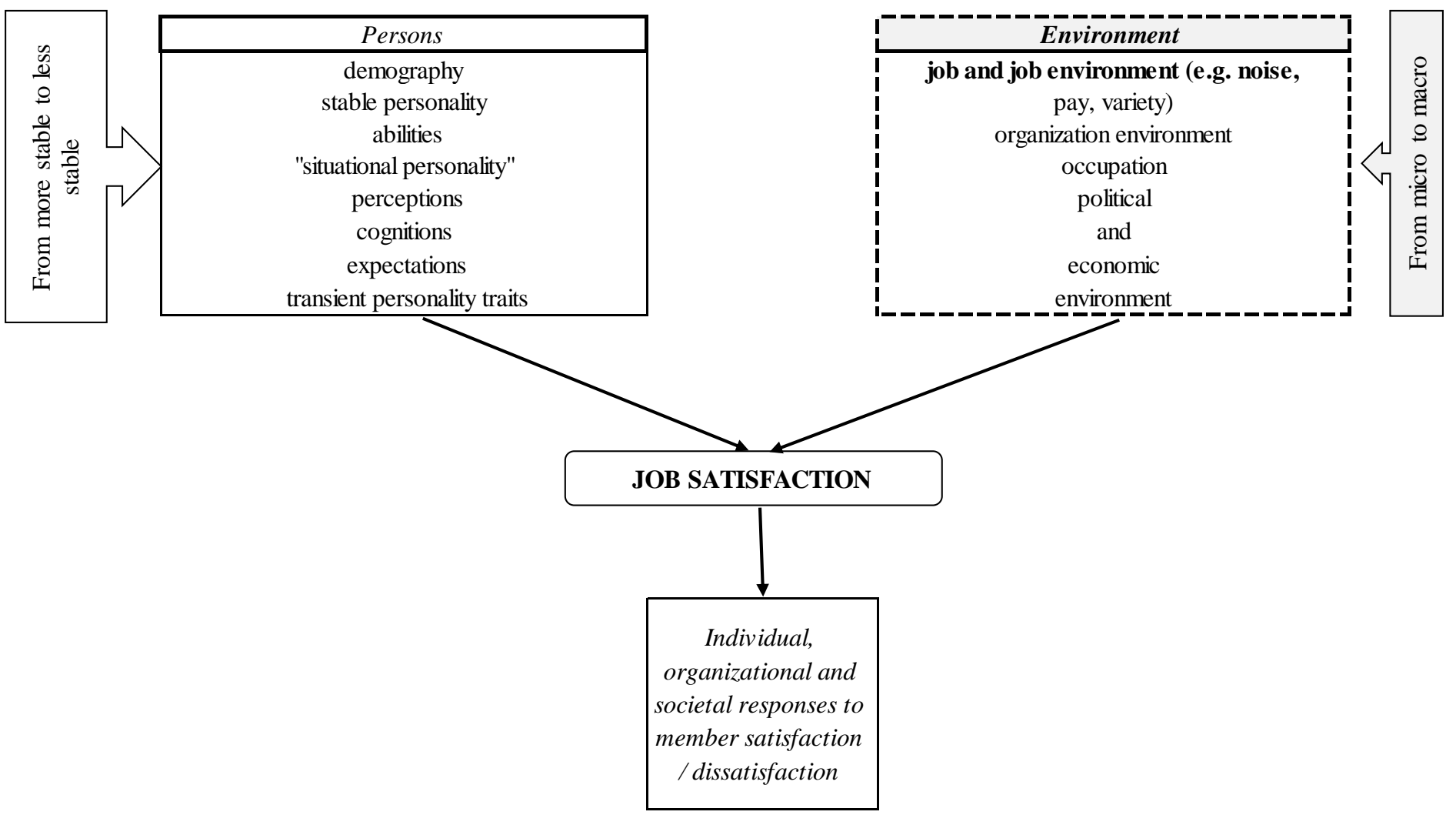

Figure 1. Principal classes of variables correlated with job satisfaction

Source: Authors adapted from Seashore \& Taber (1975) 
Figure 2

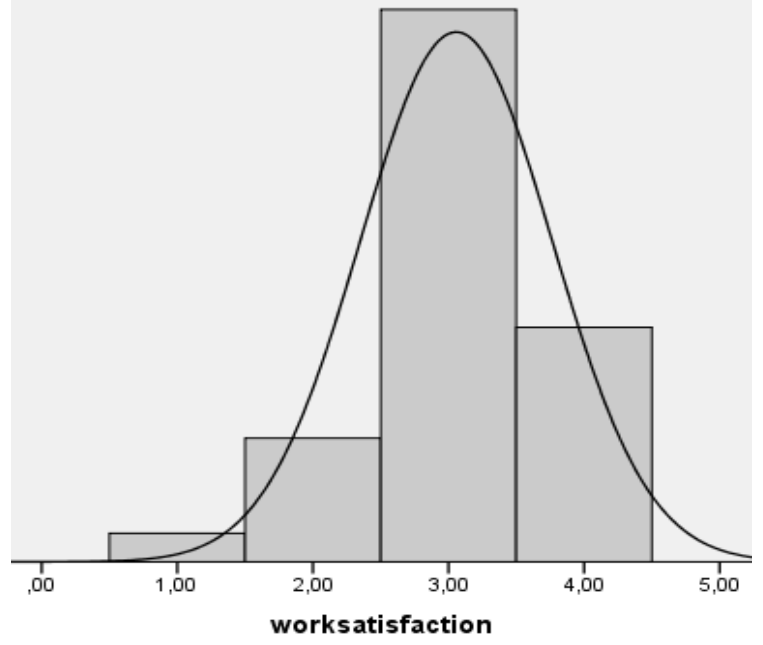

Figure 2: Job satisfaction distribution in Europe Source: EWCS 2015 


\section{Table 1. Summary statistics}

\begin{tabular}{|c|c|c|c|c|}
\hline & Min & Max & Mean & $\begin{array}{l}\text { Std. } \\
\text { Dev. }\end{array}$ \\
\hline Job Satisfaction & 1 & 4 & 3.093 & 0.6957 \\
\hline \multicolumn{5}{|l|}{ Individual characteristics } \\
\hline Gender (reference group: male) & 0 & 1 & 0.51 & 0.5 \\
\hline Age & 15 & 89 & 42,72 & 12.44 \\
\hline AgeSquared & 225 & 7,921 & 1,980 & 1,088 \\
\hline Children & 0 & 8 & 0.6 & 0.905 \\
\hline Married/partner & 0 & 1 & 0.66 & 0.475 \\
\hline \multicolumn{5}{|l|}{ Education level completed (reference group: no education) } \\
\hline Early school & 0 & 1 & 0.01 & 0.082 \\
\hline Primary & 0 & 1 & 0.03 & 0.175 \\
\hline Lower secondary & 0 & 1 & 0.15 & 0.353 \\
\hline Upper secondary & 0 & 1 & 0.42 & 0.493 \\
\hline Post-secondary & 0 & 1 & 0.09 & 0.279 \\
\hline Short cycle tertiary & 0 & 1 & 0.08 & 0.269 \\
\hline Bachelor & 0 & 1 & 0.13 & 0.334 \\
\hline Master & 0 & 1 & 0.1 & 0.299 \\
\hline Doctorate & 0 & 1 & 0.01 & 0.097 \\
\hline \multicolumn{5}{|l|}{ Contract Conditions } \\
\hline Monthly earnings & 0.04 & 271,140 & $1,630.8$ & 3,836 \\
\hline Salary change $(1=$ large decrease to $6=$ large increase $)$ & 1 & 6 & 3.1869 & 0.7705 \\
\hline Contract duration $(1=$ no contract to $6=$ unlimited duration) & 1 & 6 & 5.52 & 1.132 \\
\hline Hours wished & 0 & 168 & 34.56 & 10.238 \\
\hline \multicolumn{5}{|l|}{ Job/OrganizationalCharacteristics } \\
\hline Business size - self-employed & 0 & 1 & 0.11 & 0.311 \\
\hline Business size - from 2 to 9 employees & 0 & 1 & 0.23 & 0.419 \\
\hline Business size - from 10 to 249 employees & 0 & 1 & 0.35 & 0.478 \\
\hline Business size - more than 250 employees (reference group) & 0 & 1 & 0.31 & 0.463 \\
\hline Type of company & 0 & 5 & 1.40 & 0.804 \\
\hline Private (reference group) & 0 & 1 & 0.71 & 0.455 \\
\hline Public & 0 & 1 & 0.21 & 0.410 \\
\hline Joint private-public & 0 & 1 & 0.04 & 0.189 \\
\hline NGO & 0 & 1 & 0.02 & 0.125 \\
\hline Other & 0 & 1 & 0.02 & 0.135 \\
\hline Stress $(1=$ never to $5=$ always $)$ & 1 & 5 & 3.12 & 1.15 \\
\hline $\begin{array}{l}\text { Involvement improving workplace ( } 1=\text { strongly disagree; } 5=\text { strongly } \\
\text { agree) }\end{array}$ & 1 & 5 & 3.29 & 1.446 \\
\hline $\begin{array}{l}\text { Receive feedback from manager ( } 1=\text { strongly disagree; } 5=\text { strongly } \\
\text { agree) }\end{array}$ & 1 & 5 & 3.8286 & 1.1318 \\
\hline Trusted by management ( $1=$ strongly disagree; $5=$ strongly agree) & 1 & 5 & 4.1505 & 0.9122 \\
\hline $\begin{array}{l}\text { Career advancement prospects ( } 1=\text { strongly disagree; } 5=\text { strongly } \\
\text { agree) }\end{array}$ & 1 & 5 & 2.9135 & 1.3493 \\
\hline Get on well with colleagues ( $1=$ strongly disagree; $5=$ strongly agree) & 1 & 5 & 4,4052 & 0.7523 \\
\hline \multicolumn{5}{|l|}{ Macroeconomic Factors } \\
\hline Unemployment (\%) & 3.5 & 27.6 & 12.0071 & 7.5621 \\
\hline GDP per Capita (PPP) & 13,396 & 78,670 & 32,917 & 8,108 \\
\hline \multicolumn{5}{|l|}{ Environmental Conditions } \\
\hline $\begin{array}{l}\text { Vibrations (from hand tools, machines, etc.) }(1=\text { never; } 7=\text { all the } \\
\text { time) }\end{array}$ & 1 & 7 & 1.82 & 1.576 \\
\hline Noise $(1=$ never; $7=$ all the time $)$ & 1 & 7 & 2.11 & 1.675 \\
\hline
\end{tabular}


High temperatures $(1=$ never; $7=$ all the time $)$

Low temperatures $(1=$ never; $7=$ all the time $)$

Exposure to breathing smoke, fumes, dust $(1=$ never; $7=$ all the time $)$

Exposure to breathing vapours $(1=$ never; $7=$ all the time $)$

$7 \quad 1.62$

Exposure to chemical products $(1=$ never; $7=$ all the time $)$

$7 \quad 1.50$

1.165

Exposure to second hand smoking ( $1=$ never; $7=$ all the time $)$

$7 \quad 1.76$

1.468

Exposure to infectious materials $(1=$ never; $7=$ all the time $)$ 
Table 2: Job satisfaction and workplace environmental conditions

\begin{tabular}{|c|c|c|c|c|}
\hline Dependent variable is Job Satisfaction & (1) & (2) & (3) & (4) \\
\hline \multicolumn{5}{|l|}{ Individual characteristics } \\
\hline Gender & $\begin{array}{r}-0.001 \\
(0.845)\end{array}$ & $\begin{array}{r}0.011 \\
(0.178)\end{array}$ & $\begin{array}{r}0.008 \\
(0.310)\end{array}$ & $\begin{array}{r}0.013 \\
(0.107)\end{array}$ \\
\hline Age & $\begin{array}{r}-0.237 * * * \\
(0.000)\end{array}$ & $\begin{array}{r}-0.223 * * * \\
(0.000)\end{array}$ & $\begin{array}{r}-0.208 * * * \\
(0.000)\end{array}$ & $\begin{array}{r}-0.199 * * * \\
(0.000)\end{array}$ \\
\hline AgeSqueared & $\begin{array}{r}0.276 * * * \\
(0.000)\end{array}$ & $\begin{array}{r}0.253^{* * *} * \\
(0.000)\end{array}$ & $\begin{array}{r}0.251 * * * \\
(0.000)\end{array}$ & $\begin{array}{r}0.237 \\
(0.000)\end{array}$ \\
\hline Children & $\begin{array}{r}0.039 * * * \\
(0.000)\end{array}$ & $\begin{array}{r}0.036 * * * \\
(0.000)\end{array}$ & $\begin{array}{r}0.039 * * * \\
(0.000)\end{array}$ & $\begin{array}{r}0.036 * * * \\
(0.000)\end{array}$ \\
\hline Married/partner & $\begin{array}{r}0.014 \\
(0.081)\end{array}$ & $\begin{array}{r}0.015 \\
(0.056)\end{array}$ & $\begin{array}{r}0.012 \\
(0.123)\end{array}$ & $\begin{array}{r}0.014 \\
(0.085)\end{array}$ \\
\hline \multicolumn{5}{|c|}{ Education level completed (ref: no education) } \\
\hline Primary & $\begin{array}{r}-0.008 \\
(0.270)\end{array}$ & $\begin{array}{r}-0.002 \\
(0.772)\end{array}$ & $\begin{array}{r}-0.004 \\
(0.609)\end{array}$ & $\begin{array}{r}-0.004 \\
(0.611)\end{array}$ \\
\hline Lower secondary & $\begin{array}{c}-0.017 * \\
(0.035)\end{array}$ & $\begin{array}{r}-0.007 \\
(0.341)\end{array}$ & $\begin{array}{r}-0.003 \\
(0.662)\end{array}$ & $\begin{array}{r}-0.007 \\
(0.351)\end{array}$ \\
\hline Upper secondary & $\begin{array}{r}-0.038 * * * \\
(0.000)\end{array}$ & $\begin{array}{r}-0.005 \\
(0.583)\end{array}$ & $\begin{array}{r}-0.009 \\
(0.254)\end{array}$ & $\begin{array}{l}-0.005 \\
(0.561)\end{array}$ \\
\hline Post secondary & $\begin{array}{r}-0.038 * * \\
(0.001)\end{array}$ & $\begin{array}{r}-0.038 * * * \\
(0.000)\end{array}$ & $\begin{array}{r}-0.042 * * * \\
(0.000)\end{array}$ & $\begin{array}{r}-0.040 * * * \\
(0.000)\end{array}$ \\
\hline Short cycle tertiary & $\begin{array}{r}-0.061 * * * \\
(0.000)\end{array}$ & $\begin{array}{r}0.001 \\
(0.890)\end{array}$ & $\begin{array}{r}0.000 \\
(0.993)\end{array}$ & $\begin{array}{r}-0.002 \\
(0.792)\end{array}$ \\
\hline Bachelor & $\begin{array}{c}-0.018 * \\
(0.049)\end{array}$ & $\begin{array}{c}0.020 * \\
(0.018)\end{array}$ & $\begin{array}{c}0.021 * \\
(0.011)\end{array}$ & $\begin{array}{l}0.019 * \\
(0.021)\end{array}$ \\
\hline Master & $\begin{array}{c}-0.022 * \\
(0.039)\end{array}$ & $\begin{array}{r}-0.006 \\
(0.482)\end{array}$ & $\begin{array}{r}-0.003 \\
(0.667)\end{array}$ & $\begin{array}{r}-0.006 \\
(0.498)\end{array}$ \\
\hline Doctorate & $\begin{array}{r}-0.034 * * * \\
(0.000)\end{array}$ & $\begin{array}{r}-0.030 * * * \\
(0.000)\end{array}$ & $\begin{array}{r}-0.031 * * * \\
(0.000)\end{array}$ & $\begin{array}{r}-0.033 * * * \\
(0.000)\end{array}$ \\
\hline \multicolumn{5}{|l|}{ Contract Conditions } \\
\hline Monthly earnings & $\begin{array}{r}-0.009 \\
(0.238)\end{array}$ & $\begin{array}{r}-0.010 \\
(0.183)\end{array}$ & $\begin{array}{r}-0.010 \\
(0.184)\end{array}$ & $\begin{array}{r}-0.010 \\
(0.164)\end{array}$ \\
\hline Salary change & $\begin{array}{r}0.053 * * * \\
(0.000)\end{array}$ & $\begin{array}{r}0.054 * * * \\
(0.000)\end{array}$ & $\begin{array}{r}0.053 * * * \\
(0.000)\end{array}$ & $\begin{array}{r}0.054 * * * \\
(0.000)\end{array}$ \\
\hline Contract duration & $\begin{array}{r}0.041 * * * \\
(0.000)\end{array}$ & $\begin{array}{r}0.038 * * * \\
(0.000)\end{array}$ & $\begin{array}{r}0.039 * * * \\
(0.000)\end{array}$ & $\begin{array}{r}0.036 * * * \\
(0.000)\end{array}$ \\
\hline Hours wished & $\begin{array}{c}-0.019 * \\
(0.014)\end{array}$ & $\begin{array}{c}-0.016^{*} \\
(0.043)\end{array}$ & $\begin{array}{c}-0.019 * \\
(0.012)\end{array}$ & $\begin{array}{r}-0.018 * \\
(0.023)\end{array}$ \\
\hline \multicolumn{5}{|l|}{ Job/Organizational Characteristics } \\
\hline \multicolumn{5}{|c|}{ Business size (ref: more $\tan 250$ employees) } \\
\hline Self-employed & $\begin{array}{r}0.020 * * \\
(0.006)\end{array}$ & $\begin{array}{c}0.019 * \\
(0.010)\end{array}$ & $\begin{array}{c}0.017 * \\
(0.017)\end{array}$ & $\begin{array}{c}0.017 * \\
(0.019)\end{array}$ \\
\hline 2 to 9 employees & $\begin{array}{r}0.024 * * \\
(0.004)\end{array}$ & $\begin{array}{c}0.023^{*} \\
(0.005)\end{array}$ & $\begin{array}{r}0.015 \\
(0.078)\end{array}$ & $\begin{array}{r}0.015 \\
(0.077)\end{array}$ \\
\hline 10 to 249 employees & $\begin{array}{r}0.028 * * * \\
(0.000)\end{array}$ & $\begin{array}{r}0.030 * * * \\
(0.000)\end{array}$ & $\begin{array}{c}0.020^{*} \\
(0.010)\end{array}$ & $\begin{array}{r}0.023 * * \\
(0.004)\end{array}$ \\
\hline \multicolumn{5}{|l|}{ Type of company (ref: private) } \\
\hline Public company & $\begin{array}{r}-0.186 * * \\
(0.001)\end{array}$ & $\begin{array}{r}-0.185 * * \\
(0.001)\end{array}$ & $\begin{array}{r}-0.200 * * * \\
(0.000)\end{array}$ & $\begin{array}{r}-0.201 * * * \\
(0.000)\end{array}$ \\
\hline Joint private-public company & $\begin{array}{r}-0.094 * * * \\
(0.000)\end{array}$ & $\begin{array}{r}-0.096 * * * \\
(0.000)\end{array}$ & $\begin{array}{r}-0.101 * * * \\
(0.000)\end{array}$ & $\begin{array}{r}-0.103 * * * \\
(0.000)\end{array}$ \\
\hline $\mathrm{NGO}$ & $\begin{array}{r}-0.079 * * * \\
(0.000)\end{array}$ & $\begin{array}{r}-0.080 * * * \\
(0.000)\end{array}$ & $\begin{array}{r}-0.083 * * * \\
(0.000)\end{array}$ & $\begin{array}{r}-0.084 * * * \\
(0.001)\end{array}$ \\
\hline Others & $\begin{array}{r}-0.052 * * * \\
(0.000)\end{array}$ & $\begin{array}{r}-0.051 * * * \\
(0.000)\end{array}$ & $\begin{array}{r}-0.048 * * * \\
(0.000)\end{array}$ & $\begin{array}{r}-0.048 * * * \\
(0.000)\end{array}$ \\
\hline
\end{tabular}


Stress

Involvement improving workplace

Receive Feedback from manager

Trusted by management

Career advancement prospects

Get on well with colleagues

\section{Macroeconomic Factors}

Unemployment (\%)

GDP per Capita (PPP)

Environmental Conditions

Noise

Vibrations

High temperatures

Low temperatures

Exposure to breathing smoke, fumes, dust

Exposure to breathing vapours

Exposure to Chemical products

Exposure to second-hand smoking

Exposure to infectious materials

Perceived health and safety risks

$$
\text { F }
$$

(p-value)

Adjusted R_squared

Controls

Country

$$
\begin{array}{rrrr}
0.193 * * * & 0.184 * * * & 0.165 * * * & 0.161 * * * \\
(0.000) & (0.000) & (0.000) & (0.000) \\
& & & \\
0.142 * * * & 0.111 * * * & 0.106 * * * & 0.107 * * * \\
(0.000) & (0.000) & (0.000) & (0.000) \\
0.122^{* * *} & 0.118^{* * *} & 0.114 * * * & 0.113 * * * \\
(0.000) & (0.000) & (0.000) & (0.000) \\
0.168 * * * & 0.169 * * * & 0.166 * * * & 0.162 * * * \\
(0.000) & (0.000) & (0.000) & (0.000) \\
0.174 * * * & 0.247 * * * & 0.239 * * * & 0.237 * * * \\
(0.000) & (0.000) & (0.000) & (0.000) \\
0.249 * * * & 0.140 * * * & 0.142 * * * & 0.140 * * * \\
(0.000) & (0.000) & (0.000) & (0.000)
\end{array}
$$

$\begin{array}{llll}0.263 & 0.245 & 0.222 & 0.218\end{array}$

$\begin{array}{llll}(0.102) & (0.141) & (0.180) & (0.189)\end{array}$

$0.223 * * \quad 0.201 * * \quad 0.176 * * \quad 0.175 * *$

$\begin{array}{llll}(0.001) & (0.001) & (0.004) & (0.005)\end{array}$

$0.028 * * \quad 0.031 * *$

(0.004) $\quad(0.002)$

$-0.052 * * * \quad-0.042 * * *$

$(0.000) \quad(0.000)$

$0.008 \quad 0.013$

$(0.397) \quad(0.151)$

$-0.039 * * * \quad-0.033 * * *$

$(0.000) \quad(0.000)$

$\begin{array}{ll}-0.001 & 0.007\end{array}$

$(0.938) \quad(0.494)$

$-0.021 * \quad-0.018$

$(0.033) \quad(0.071)$

$0.004 \quad 0.012$

$(0.669) \quad(0.221)$

$-0.021 * * \quad-0.019 *$

$(0.007) \quad(0.013)$

$\begin{array}{ll}-0.012 & -0.002\end{array}$

$(0.153) \quad(0.788)$

$\begin{array}{lr}-0.120 * * * & -0.115^{* * *} \\ (0.000) & (0.000)\end{array}$

$\begin{array}{llll}104.983 & 92.196 \quad 107.938 & 93.902\end{array}$

$\begin{array}{llll}(0.000) \quad(.000) \quad(.000) & (.000)\end{array}$

$\begin{array}{llll}0,312 & .315 & .324 & .325\end{array}$

Note. All entries are standardized regression coefficients; $* \mathrm{p}<.05 ; * * \mathrm{p}<.01 ; * * * \mathrm{p}<.001$ 


\section{Appendix Table 1. Job Satisfaction: previous literature}

\section{Authors}

Title

Arampatzi et al. (2015)

Augner (2015)

Beckmann et al (2009)

Blanchflower and Oswald (1999)

Bockerman, Brysson, Ilmakunnas (2015)

Brown and McIntosh (1998)

Card et al. (2012)

Clark (2005)
"Financial distress and happiness of employees in times of economic crisis"

"Job satisfaction in the European Unition: The role of macroeconomic, personal and job related factors"

"Fixed-term employment, work organization and job satisfaction: Evidence from German individual-level data"

"Well-being, insecurity and the decline of American job satisfaction"

"Does high involvement management improve worker wellbeing?"

"If you're happy and you know it... job satisfaction in the low wage service sector"

"Inequality at work: the effect of peer salaries on job satisfaction"

"Your money or your life: changing job quality in OECD countries"
Take-home message

Unemployment and inflation are associated with lower levels of LS for employees in bad financial situation or who expect worse future financial situation. Employed people with good financial situation and good prospects are not affected by the crisis

Beside personal, job related and organizational factors that influence JS, the macroeconomic perspective has to be considered too.

Fixed-term workers and their permanent counterparts respond differently to a number of organizational practices related to JS, such us task diversity, employee involvement, social relations at work, general working conditions, and career prospects. Based on German data.

The cross-section pattnerns in job satisfaction are similar across advanced nations (negative effecty of expectation of job loss, U-shaped in age, greater for wome, whites, high pay, supervisors, public sector, self-employed, short commute, - no effect for education and job tenure). Three companies were analyzed: a restaurant, a hotel and a supermarket.

Finnish employees exposed to high involvement management (HIM) practices have higher subjective wellbeing,fewer accidents but more short absence spells

Satisfaction with short-term rewards and long-term prospects are found to be far more influential in determining overall satisfaction than contentment with social relationships or work intensity

Negative comparisons about wages matter more than positive comparisons for a worker's perceived job satisfaction. Based on data from California public employees

Uses both cross section (ISSP) and panel data (BHPS) to examine changes in job quality in OECD countries. Despite rising wages and falling hours, overall job satisfaction is either stable or declining. Not due to changes in the type of workers or job values. Likely due to stress and hard work. 


Authors

Clark (2015)

Clark and Oswald (1994)

Clark, Oswald, Warr (1996)

De Neve and Ward (2017)

Garcia-Mainar et al (2015)

Green, Felstead, Gallie and Inanc (2016)

Green, Mostafa, Parent-Thirion, Vermeylen, van Houten, Biletta, Lyly-Yrjanainen (2013)

Harter, J., T. Hayes and F. Schmidt (2002)

Mayer (2015)

Mohr and Zoghi (2008)
Title

"What makes a good job? Job quality and job

satisfaction"

"Unhappiness and Unemployment"

"Is job satisfaction U-shaped in age?"

"Happiness at work"

"Workplace environmental conditions and life satisfaction in Spain"

"Job-Related Well-Being Through the Great Recession"

"Is job quality becoming more unequal?"

"Business-unit-level relationship between employee satisfaction, employee engagement and business outcomes: A meta-analysis"

"Recession and life satisfaction in 35 countries"

"High-invovement work design and job satisfaction"
Take-home message

Job satisfaction is important to well-being, but intervention may be needed only if

markets are impeded from improving job quality

Relationship between being unemployed and worse mental health (British data)

U-shape relationship between age and JS (and satisfaction with pay, and satisfaction with the work itself) for a large sample of British employees

A closely look at the relationship between work and happiness in 150 countries

Poor air quality and high noise levels in theworkplace markedly diminish life satisfaction in Spain

The 2006-2012 fall in job-related well-being is partly accounted for by accelerations in the pace of workplace change, rising job insecurity, increased effort and changing participation. Based on British data

Examines trends in non-wage aspects of job quality in Europe: Work quality, work intensity, good physical environment, and working time quality Uses 1995 to 2010 data of the European Working Conditions Survey. Draws differences according to varieties of capitalism across countries.

Changes in management practices that increase employee satisfaction may increase business-unit outcomes, including profits.

Job loss and a reduction in staple consumption have a particularly strong negative effect on subjective well-being

JS is positively relationated with high involvement practices 
Mumford and Smith (2014)

Origo and Pagani (2008)

Osterman (2013)

Oswald (2002)

Seashore and Taber (1975)

Souza-Poza et al. (2000)

Tay and Harter (2013)

Viñas-Bardolet et al. (2015)
"Peer salaries and gender differences in job satisfaction in the workplace"

"Workplace flexibility and job satisfaction: some evidence from Europe"

"Introduction to the Special Issue on Job Quality: What does it Mean and How Might We Think About It?"

"Are you happy at work? Job satisfaction and work-life balance in the US and Europe"

"Job satisfaction indicators and their correlates"

"Well-being at work: a cross national analysis of the levels and determinants of job satisfaction"

"Economic and labor market forces matter for worker well-being"

"Determinants of Job Satisfaction, the Role of Knowledge-based work: An illustration from Spain"
Gender differences in JS: Men display behaviour characteristic of competitiveness while women do not

A positive link was found between functional flexibility and job satisfaction and either no effect or a negative impact of quantitative flexibility. The positive impact of functional flexibility is greater when considering satisfaction for intrinsic aspects of the job.

The Cornell ILR School and the ILR Review sponsored a conference on job quality (2011) that led a special issue in Job Quality (Components of Job Quality: Compensation, Diversity, Control, Stress)

\section{Summary paper}

Variables correlated to Job Satisfaction

General trends and determinants of JS across the world

From a worldwide sample, they showed that economic factors (GDP and job optimism) are associated with job satisfaction beyond demographic and job factors. From USA data, they concluded that unemployment is associated with job dissatisfaction

Knowledge-based Spanish workers perceived significantly higher job satisfaction than the other workers 
